\title{
Study of serotonin transporter gene polymorphism Stin2 in two Siberian indigenous populations
}

\author{
Mira Khantemirova \\ Laboratory of computer genomics \\ Novosibirsk State University \\ Novosibirsk, Russia \\ hantemiramira@mail.ru \\ Anatoly Bragin \\ Laboratory of computer genomics \\ Novosibirsk State University \\ Novosibirsk, Russia \\ ibragim@bionet.nsc.ru
}

\author{
Daria Lichman \\ Laboratory of computer genomics \\ Novosibirsk State University \\ Novosibirsk, Russia \\ daria.lichman@gmail.com \\ Vladimir Naumenko \\ Laboratory of behavioral \\ neurogenomics \\ Institute of Cytology and Genetics, \\ SB RAS \\ Novosibirsk, Russia \\ naumenko2002@bionet.nsc.ru
}

\author{
Daria Bazovkina \\ Laboratory of behavioral \\ neurogenomics \\ Institute of Cytology and Genetics, \\ SB RAS \\ Novosibirsk, Russia \\ daryabazovkina@gmail.com \\ Ludmila Osipova \\ Laboratory of computer genomics \\ Novosibirsk State University \\ Novosibirsk, Russia \\ ludos77@yandex.ru
}

\begin{abstract}
Serotonin (5-HT) participates in regulation of emotions, mood, sleep, appetite, and cognitive processes. Serotonin transporter (5-HTT, SERT) modulates serotoninergic neurotransmission through reuptake of 5-HT from the synaptic cleft. A variable number tandem repeat polymorphism found in intron 2 of the 5-HTT gene (Stin2 polymorphism) influences 5HTT expression and is associated with anxiety, depression, suicidal behavior, obsessive-compulsive disorder. The aim of the present study was to investigate Stin2 allele frequencies in populations of Tundra Nenets and Nganasans inhabiting north and east Siberia. The frequency of the STin2.10 allele was $72.1 \%$ in Tundra Nenets and $\mathbf{8 9 . 4 \%}$ in Nganasans. The data obtained are consistent with the uniform geographic gradient of STin2 alleles, with low frequency of the STin2.10 allele in East Asia and its increase towards west.
\end{abstract}

Keywords — serotonin, serotonin transporter, 5-HTT, SERT, Stin2, polymorphism, Tundra Nenets, Nganasans

\section{Introduction}

Serotonin (5-hydroxytryptamine, 5-HT) is a signaling molecule widely distributed in the mammalian central nervous system (CNS) and in peripheral tissues. It acts both as a hormone and a neurotransmitter. As a neurotransmitter, 5-HT participates in regulation of emotions, mood, sleep, appetite, and cognitive processes [1]. Dysfunction of the central serotonin system is involved in the etiology of various mental disorders, including depression, suicidal behavior, excessive aggression, anxiety, addiction, obsessive-compulsive disorder, attention deficit/hyperactivity disorder and autism $[1,2]$.

Serotonin transporter (5-HTT, SERT) is localized in the membranes of presynaptic neurons and is responsible for reuptake of 5-HT from the synaptic cleft thus modulating serotoninergic neurotransmission [3]. Accordingly, 5-HTT is the major target of the selective serotonin reuptake inhibitors (SSRIs), a set of medications widely used to treat depression, anxiety, ADHD and other emotional and behavioral disorders [4].

The 5-HTT protein is encoded by a single gene SLC6A4 (Soluble carrier family 6, member 4) [5]. There are two variable number tandem repeat (VNTR) polymorphisms described for this gene. One is a $43 \mathrm{bp}$ insertion/deletion $\sim 1.2$ $\mathrm{kb}$ upstream of the transcription start site, referred to as the 5-
HTT gene-linked polymorphic region (5-HTTLPR) [6]. It has been shown that 5-HTT expression and 5-HT uptake in the cells of L/S and S/S genotypes are 1.5-2-fold lower than in the cells of L/L genotype [7]. The second VNTR found in intron 2 contains most commonly 9,10 or 12 copies of a $16-17$ bp repeat (Stin2.9, Stin2.10 and Stin2.12 alleles respectively) [8]. It has been shown that Stin2 polymorphism influences 5-HTT expression and response to transcription factors $[9,10]$. There is evidence of association of these polymorphisms with anxiety [7, 11], depression [8, 12], alcohol dependence [13], suicidal behavior [14], obsessive-compulsive disorder [15].

Allele frequencies for 5-HTTLPR and Stin2 polymorphisms have been studied in different populations [16-18], including Russians [11] and other people living in Russian Federation $[16,19]$. However, to date, there was no information about these polymorphisms in Tundra Nenets and Nganasans inhabiting north Siberia. Accordingly, the aim of the present study was to investigate Stin2 allele frequencies in the samples of Tundra Nenets and Nganasans.

\section{Methods}

\section{Sample collection}

Blood samples were collected during expeditions to Yamalo-Nenets Autonomous Okrug and Taymyrsky Dolgano-Nenetsky District from 1988 to 2009. Each participant was informed of the purpose of the study, and written informed consent was obtained from all participants. Each volunteer filled out a questionnaire to collect personal data, including their nationality and the nationalities of their parents and grandparents. Subjects of mixed ethnicity or close relatives were excluded from this study. The final samples included 179 Tundra Nenets and 109 Nganasans.

\section{Genotyping}

Genomic DNA was extracted from peripheral blood using standard phenol-chloroform method. Genotyping was performed using polymerase chain reaction (PCR) followed by separation of fragments in a $2 \%$ agarose gel stained with ethidium bromide. Primer sequences were 5'GTCACTATCACAGGCTGCGAG-3' and 5'TCTTCCTAGTCTTACGCCAGTG-3'. The PCR mixture $(20 \mu \mathrm{l})$ contained $10 \mathrm{ng}$ of DNA, $2 \mathrm{pM}$ of primers, $200 \mu \mathrm{M}$ of each dNTP, $1 \mathrm{U}$ of Taq polymerase and 1X PCR buffer $(67$ $\mathrm{mM}$ Tris- $\mathrm{HCl} \mathrm{pH} 8.8,16 \mathrm{mM}$ (NH4)2SO4, 0.1\% Tween 2.0, 
$1.0 \mathrm{mM} \mathrm{MgC12)}$. The PCR conditions were as follows: initial denaturation for $3 \mathrm{~min}$ at $94{ }^{\circ} \mathrm{C} ; 35$ cycles of $15 \mathrm{~s}$ at $94{ }^{\circ} \mathrm{C}$, $30 \mathrm{~s}$ at $64{ }^{\circ} \mathrm{C}, 40 \mathrm{~s}$ at $72{ }^{\circ} \mathrm{C}$; and final incubation at $72{ }^{\circ} \mathrm{C}$ for $2 \mathrm{~min}$.

\section{Statistical analysis}

Correspondence of genotype frequencies to the HardyWeinberg equilibrium was assessed using Pearson's chisquared $\left(\chi^{2}\right)$ criterion. In the Nganasan sample, we found no $10 / 10$ genotypes. So these homozygotes were combined with the heterozygotes to assess the correspondence to HardyWeinberg equilibrium. Differences in allele frequencies between the populations were estimated using a $\chi 2$ test.

\section{Results}

Genotype counts and allele frequencies for STin2 are shown in Table 1. The distribution of genotypes was in accordance with Hardy-Weinberg equilibrium in the samples of Nenets $(p=0.065)$ and Nganasans $(p=0.771)$. We did not find carriers of the 9-repeat allele in either of the two samples.

Both indigenous populations studied have higher frequencies of Stin2.12 allele compared to Russians (60\% for the published Russian sample [18], $\mathrm{p}<0.001$ ).

\section{Conclusion}

The data obtained are consistent with the uniform geographic gradient of STin2 alleles, with low frequency of the STin2.10 allele in East Asia and its increase towards west. The information on the Stin2 allele frequency in indigenous populations may be further used in personalized medicine in order to choose the optimal treatment options for psychiatric disorders.

TABLE I. Genotype And Allele Distribution For Stin2

\begin{tabular}{|l|l|c|c|c|c|c|}
\hline \multirow{2}{*}{ Population } & & \multicolumn{3}{|c|}{ Genotype count } & \multicolumn{2}{c|}{ Alleles, \% } \\
\cline { 2 - 7 } & $\boldsymbol{N}$ & $\mathbf{1 2 / 1 2}$ & $\mathbf{1 2 / 1 0}$ & $\mathbf{1 0 / 1 0}$ & $\mathbf{1 2}$ & $\mathbf{1 0}$ \\
\hline Nenets & 179 & 88 & 82 & 9 & 72.1 & 27.9 \\
\hline Nganasans & 109 & 86 & 23 & 0 & 89.4 & 10.6 \\
\hline
\end{tabular}

\section{ACKNOWLEDGMENT}

The work was supported by the Russian Scientific Foundation, project 19-15-00219.

\section{REFERENCES}

[1] I. Lucki, "The spectrum of behaviors influenced by serotonin," Biol. Psychiatry, vol. 44, pp. 151-162, August 1998.

[2] B. Olivier, "Serotonin: A never-ending story," Eur. J. Pharmacol., vol. 753, pp. 2-18, April 2015.

[3] R. D. Blakely, L. J. De Felice, and H. C. Hartzell, "Molecular physiology of norepinephrine and serotonin transporters," J. Exp. Biol., vol. 196, pp. 263-281, November 1994.

[4] J. Hyttel, "Pharmacological characterization of selective serotonin reuptake inhibitors (SSRIs)," Int. Clin. Psychopharmacol., vol. 9 Suppl. 1, pp. 19-26, March 1994.

[5] S. Ramamoorthy, A. L. Bauman, K. R. Moore, H. Han, T. Yang-Feng, A. S. Chang, et al., "Antidepressant- and cocaine-sensitive human serotonin transporter: molecular cloning, expression, and chromosomal localization,” Proc. Natl. Acad. Sci., vol. 90(6), pp. 2542-2546, March 1993.

[6] A. Heils, A. Teufel, S. Petri, G. Stöber, P. Riederer, D. Bengel, et al., "Allelic Variation of Human Serotonin Transporter Gene Expression," J. Neurochem., vol. 66(6), pp. 2621-2624, November 2002.

[7] K.-P. Lesch, D. Bengel, A. Heils, S. Z. Sabol, B. D. Greenberg, S. Petri, et al., "Association of Anxiety-Related Traits with a Polymorphism in the Serotonin Transporter Gene Regulatory Region," Science (80- ), vol. 274(5292), pp. 1527-1531, November 1996

[8] A. D. Ogilvie, S. Battersby, V. J. Bubb, G. Fink, A. J. Harmar, G. M. Goodwim, et al., "Polymorphism in serotonin transporter gene associated with susceptibility to major depression," Lancet (London, England), vol. 347(9003), pp.731-733, March 1996.

[9] E. A. Lovejoy, A. C. Scott, C. E. Fiskerstrand, V. J. Bubb, and J. P. Quinn, "The serotonin transporter intronic VNTR enhancer correlated with a predisposition to affective disorders has distinct regulatory elements within the domain based on the primary DNA sequence of the repeat unit," Eur. J. Neurosci., vol. 17(2), pp. 417-420. January 2003.

[10] E. Klenova, A. C. Scott, J. Roberts, S. Shamsuddin, E. A. Lovejoy, S. Bergmann, et al., "YB-1 and CTCF differentially regulate the 5-HTT polymorphic intron 2 enhancer which predisposes to a variety of neurological disorders," J. Neurosci., vol. 24(26), pp. 5966-5973, June 2004.

[11] A. V. Kazantseva, D. A. Gaysina, G. G. Faskhutdinova, T. Noskova, S. B. Malykh, and E. K. Khusnutdinova, "Polymorphisms of the serotonin transporter gene (5-HTTLPR, A/G SNP in 5-HTTLPR, and STin2 VNTR) and their relation to personality traits in healthy individuals from Russia," Psychiatr. Genet., vol. 18(4), pp. 167-176, August 2008.

[12] N. Goldman, D. A. Glei, Y.-H. Lin, and M. Weinstein, "The serotonin transporter polymorphism (5-HTTLPR): allelic variation and links with depressive symptoms," Depress. Anxiety, vol. 27(3), pp. 260-269, March 2010.

[13] M. Laucht, J. Treutlein, B. Schmid, D. Blomeyer, K. Becker, A. F. Buchmann, et al., "Impact of Psychosocial Adversity on Alcohol Intake in Young Adults: Moderation by the LL Genotype of the Serotonin Transporter Polymorphism," Biol. Psychiatry, vol. 66(2), pp. 102-109, July 2009.

[14] C. L. de Lara, A. Dumais, G. Rouleau, A. Lesage, M. Dumont, N. Chawky, et al., "STin2 Variant and Family History of Suicide as Significant Predictors of Suicide Completion in Major Depression," Biol. Psychiatry, vol. 59(2), pp. 114-120, January 2006.

[15] E. Baca-Garcia, C. Vaquero-Lorenzo, M. Diaz-Hernandez, B. Rodriguez-Salgado, H. Dolengevich-Segal, M. Arrojo-Romero, et al., "Association between obsessive-compulsive disorder and a variable number of tandem repeats polymorphism in intron 2 of the serotonin transporter gene," Prog. Neuro-Psychopharmacology Biol. Psychiatry, vol. 31(2), pp. 416-420, March 2007.

[16] J. D. Murdoch, W. C. Speed, A. J. Pakstis, C. E. Heffelfinger, and K. K. Kidd, "Worldwide population variation and haplotype analysis at the serotonin transporter gene SLC6A4 and implications for association studies,” Biol. Psychiatry, vol. 74(12), pp. 879-889, December 2013.

[17] J. Gelernter, H. Kranzler, and J. F. Cubells, "Serotonin transporter protein (SLC6A4) allele and haplotype frequencies and linkage disequilibria in African- and European-American and Japanese populations and in alcohol-dependent subjects," Hum. Genet., vol. 101(2), pp. 243-246, December 1997.

[18] D. Gaysina, A. Zainullina, R. Gabdulhakov, and E. Khusnutdinova, "The serotonin transporter gene: polymorphism and haplotype analysis in Russian suicide attempters," Neuropsychobiology. vol. 54(1), pp.70-74, October 2006.

[19] A. S. Gureyev, A. A. Kim, Y. D. Sanina, V. I. Shirmanov, V. A. Koshechkin, O. P. Balanovskiy, et al., "Serotonin transporter gene 5HTTLPR VNTR allele frequency distribution in Africa and Eurasia," Ekol. Genet., vol. 12(3), pp. 71-86, 2014. 